\title{
Exploration of Microalgae Photobioreactor (PBR) in Tropical Climate Building Envelope
}

\author{
Mohd Tajul Izrin Mohd Tajul Hasnan, Puteri Mayang Bahjah Zaharin
}

${ }^{1}$ Centre of Studies for Architecture, Faculty of Architecture, Planning and Surveying (FSPU), Kompleks Alam Bina dan Seni Reka, Universiti Teknologi MARA (UiTM), Kampus Puncak Alam, 42300, Bandar Puncak Alam, Selangor, Malaysia

tajulizrin@gmail.com, bahjah55@gmail.com

Tel: +0193965334

\begin{abstract}
The building sector in Malaysia consumes up to half of the electricity generated in the country. Therefore, there are needs to have a continuous effort to promote microalgae as part of an innovative building envelope system. This paper intends to investigate the potentiality of implementing the microalgae photobioreactor (PBR) in building envelopes in Malaysia. The findings from the precedent studies are synthesised into ten (10) parameters and translated into four (4) design modules. In conclusion, the suggested parameters are crucial in establishing microalgae photobioreactor (PBR) as a suitable prospect for energy efficiency in building envelopes in the tropical climate.
\end{abstract}

Keywords: energy consumption; microalgae; photobioreactor; building envelope

eISSN: 2398-4287@ 2020. The Authors. Published for AMER ABRA CE-Bs by e-International Publishing House, Ltd., UK. This is an open access article under the CC BYNC-ND license (http://creativecommons.org/licenses/by-nc-nd/4.0/). Peer-review under responsibility of AMER (Association of Malaysian Environment-Behaviour Researchers), ABRA (Association of Behavioural Researchers on Asians) and CE-Bs (Centre for Environment-Behaviour Studies), Faculty of Architecture, Planning \& Surveying, Universiti Teknologi MARA, Malaysia.

DOI: https://doi.org/10.21834/ebpj.v5i14.2212

\subsection{Introduction}

The development, studies and interest in algae integrated building envelopes are not a new concept in the architecture fields. Application of algae in building facades sets new standards in renewable clean energy in the building industry. Some several designers and architects propose the application of algae in their buildings or art installation. For example, the world first algae facade integrated building, the BIQ House in Hamburg, Germany is enclosed with an algae panel as an active shading device. Other than that, the first place winning scheme for the 2011 Ideas Competition by HOK Architects demonstrates the ideas of installing algae photobioreactor (PBR) tube on the top surfaces of the opaque building envelopes of the GSA federal building in Los Angeles. Recently, HOK also proposed a conceptual design of the net energy zero battery Park Project in San Francisco which incorporated algae PBR panels to cultivate algae and reduce carbon dioxide.

The green building regulations established around the world are intended to provide more efficient energy and water consumption, improved indoor air quality and better management of liquid and solid wastes. These objectives are attained through various design methods. In tropical climate buildings, the use of sun shading devices for large openings help to prevent heat gain into the building, thus reducing the indoor air temperature.

The integrated algae facade system sets new standards in sustainable design. The implementation of algae in building facade not only able to reduce energy consumption, but also generates energy through biofuel and biomass and release oxygen to improve its indoor air quality. This approach provides a comprehensive sustainable solution and improves the energy performance for the building.

eISSN: 2398-4287@ 2020. The Authors. Published for AMER ABRA CE-Bs by e-International Publishing House, Ltd., UK. This is an open access article under the CC BYNC-ND license (http://creativecommons.org/licenses/by-nc-nd/4.0). Peer-review under responsibility of AMER (Association of Malaysian Environment-Behaviour Researchers), ABRA (Association of Behavioural Researchers on Asians) and cE-Bs (Centre for Environment-Behaviour Studies), Faculty of Architecture, Planning \& Surveying, Universiti Teknologi MARA, Malaysia.

DOI: https://doi.org/10.21834/ebpj.v5i14.2212 


\subsection{Problem Statement}

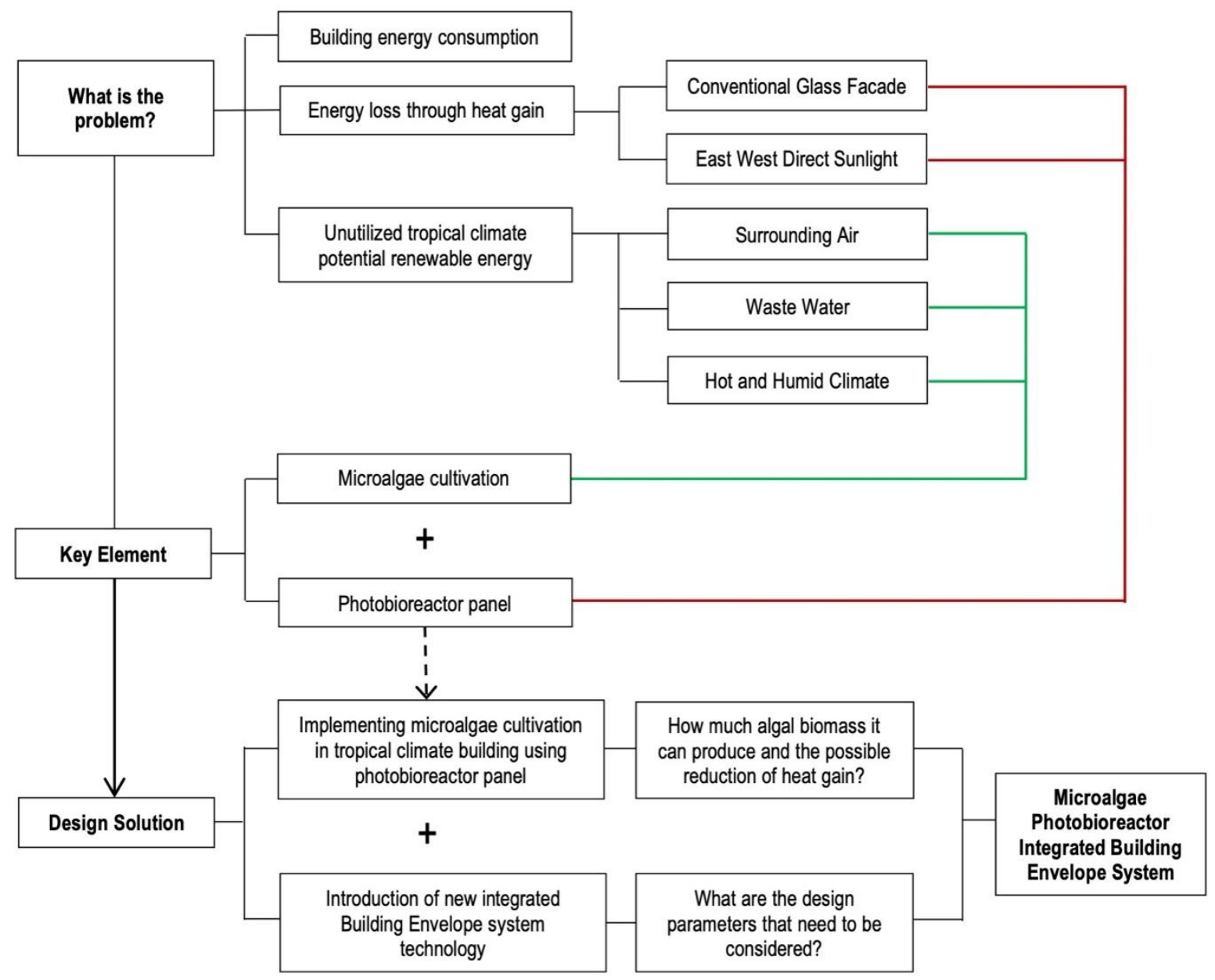

Figure 1: The Mapping of Building Energy Consumption Problem - Solution (Source: Author)

Malaysia being a developing country with a fast-growing population and blooming economic movement, is burdened by the increasing demand for energy supply. According to the United Nations Environment Programme (UNEP), buildings use about $40 \%$ of the global energy and emit approximately $33 \%$ of the greenhouse gas (GHG) emissions. Buildings in Malaysia consume about one-third of the total electricity usage within the country. A survey from the National Energy Efficiency Action Plan (NEEAP) shows that the application of MS1525:2014 Code of Practice on energy efficiency and the use of renewable energy for non-residential buildings can help to reduce the energy consumption from $200-250 \mathrm{kWh} / \mathrm{m} 2 /$ year to $135 \mathrm{kWh} / \mathrm{m} 2 /$ year. Hence, the urgency of emerging energy efficiency initiative and utilising renewable energy in new buildings in the country is highly recommendable for the time being to help achieve sustainable development goals (SDGs). In Malaysia, roofs and walls are the primary sources for heat transfer in typical buildings. Besides that, Malaysia being a hot and humid climate country, has continuous exposure of solar radiation towards building surfaces which resulted in the increasing amount of heat (Mirrahimi et al., 2016). In order to ensure comfortable and desirable thermal conditions in buildings, the building surfaces must be directly or indirectly secured to minimize heat gain into the building. There are some effective strategies that can be used to minimise heat emission in buildings, such as appropriate shading, right building orientation, provide vegetation surrounding the building and proper materials for building façades.

The design of building envelope can directly affect the energy consumption of a building as it functions as a thermal barrier by reducing glare and risk of overheating and minimising water penetration from rain all year long. The building envelope is a physical separation between the internal and external parts of the building, which consists of walls, floors, roofs, windows and doors. The options in selecting the best strategy of building envelope consider factors such as the area ratio of window to wall, shading system, exterior wall thermal insulation and the types of glazing. Other than the use of solar panel to reduce building energy consumption, there is less renewable energy solution to the problem. 
As such, this paper intends to investigate the potentiality of implementing the microalgae photobioreactor (PBR) as a suitable prospect for energy efficiency in building envelopes in Malaysia. Consequently, the objective of this paper is as follows:

1) To identify the application of microalgae PBR on building envelopes in existing building designs

2) To determine the design parameters for the application of microalgae PBR on building envelopes in Malaysia

3) To propose a suitable building design that utilise the application of microalgae PBR on building envelopes in Malaysia

\subsection{Literature Review}

\subsection{Introduction to Microalgae}

Algae are photosynthetic organisms that can be found in aquatic habitats such as lakes, ponds, rivers, oceans, and wastewater and are classified as macroalgae and microalgae. Macroalgae are multicellular while microalgae are single microscopic cells that are rich in carbon compounds (Khan et al., 2018) and can be utilized for commercial use through the extraction of chlorophyll (Slade and Bauen, 2013).

\subsection{Potentials of Microalgae}

Microalgae are able to convert ten (10) times greater solar energy into chemical energy by bio-fixation of carbon dioxide (Sathasivam et al., 2017), thus reducing the greenhouse gas (GHG) emissions. According to Zhou et al. (2013), microalgae help to fix the carbon dioxide into a source of biofuel. This is supported by Yeang (2008) that discusses the substitution of fossil fuels with biofuels as an option to achieve a sustainable future which could power future buildings and cars. Besides that, an experiment in the tropical climate building by Ismail and Al-Obaidi (2018), shows that direct supply of carbon dioxide to microalgae flat panel PBR has succeeded in reducing heat gain up to $44.9 \%$ solar radiation. This proves the significant potentiality of microalgae as a sun-shading device for tropical climate buildings. Moreover, Klinthong et al. (2015) state that microalgae require less water and beat the other renewable resources with their multiple potentials to absorb carbon dioxide, recycle wastewater, and release oxygen. According to Randrianarison and Ashraf (2017), microalgae cultivation are useful in the waste treatment process as it absorbs nutrients from wastewater to produce oxygen.

\subsection{The Application of Microalgae in Integrated Building Envelope}

The use of algae on building envelopes possesses many benefits. According to Talaei et al. (2017), algae photobioreactors (PBR) that are integrated with the building facades can absorb solar radiations to generate energy. It also acts as daylight regulators and provides suitable shading device from the direct sunlight and glare with an average shading coefficient up to $67 \%$. The followings are buildings which integrate microalgae PBRs on its building envelopes.

\subsubsection{BIQ Building, Hamburg, Germany}

An existing building built in April 2013, the BIQ Building is the first algae-powered building in the world. The building facades are equipped with a second outer shell which produces microalgae that help to generate energy into the building. The microalgae convert sunlight to biomass through the biochemical process, which reduces the carbon dioxide emission through the building facades.

\subsubsection{Process Zero Concept Building, Los Angeles, California, USA}

The Process Zero Concept Building is the top winner for Metropolis magazine's Next Generation® Design Competition in 2011. It provides net-zero energy solutions for a 46-year-old federal office building. The proposal is able to reduce the building's overall energy demand by $84 \%$ through the integration of light wells for daylighting, louvres for natural ventilation, and microalgae bioreactor system which absorbs solar radiation to produce lipids for fuel production on-site and provides shading to internal spaces of the building.

\subsubsection{Green Loop Tower, Chicago, Illinois}

The Green Loop Tower is a design proposal in 2014 for an algae retrofitting of the marina city towers in Chicago. The building exploits the utility of urban decarbonization by inserting loops of PBRs surrounding the building facades. The loops absorb solar radiation and reduce the infiltration of carbon dioxide through the usage of wind power turbines that catch, filter and convert the carbon dioxide to oxygen that is released to the city's atmosphere.

\subsubsection{In Vivo, Paris, France}

The winner of the Réinventer Paris competition in 2016, the In Vivo building, is designed with active microalgae bio facade. The energy generated from the microalgae PBRs is used for domestic hot water and internal heating.

\subsection{Microalgae cultivation in building envelopes}

According to Qiu (2014), microalgae are better suited for cultivation in energy production due to their growth rate and high lipid content. Mass cultivation of microalgae requires an appropriate culture system. Biloria and Thakkar (2019), states that microalgae 
cultivation involves the use of daylight, carbon dioxide and organic carbon as a source of energy to produce biomass. There are two (2) major systems used in microalgae cultivation which are the open pound and closed-looped photobioreactor (PBR). For building envelopes, closed-looped PBRs are widely used. Pruvost (2014), suggests that symbiosis of microalgae cultivation with buildings specifically in PBR facade is able to produce about $200 \mathrm{~g}$ per $\mathrm{m}^{3}$ each day of dry biomass. Table 1 indicates the consideration of various factors in maximizing the microalgae cultivation on building envelopes.

Table 1: The consideration of factors to maximize microalgae cultivation on building envelopes

\begin{tabular}{|c|c|c|c|c|c|c|c|c|}
\hline Parameters & $\begin{array}{c}\text { Khan, Shin } \\
\& \text { Kim } \\
(2018)\end{array}$ & $\begin{array}{l}\text { Heo et al. } \\
(2018)\end{array}$ & $\begin{array}{c}\text { Chemodanov } \\
\text { et al. } \\
\text { (2017) }\end{array}$ & $\begin{array}{l}\text { Wilkinson et } \\
\text { al. (2017) }\end{array}$ & $\begin{array}{l}\text { Elliot } \\
\text { (2016) }\end{array}$ & $\begin{array}{l}\text { Sledgers } \\
(2014)\end{array}$ & $\begin{array}{l}\text { Elrayies } \\
(2018)\end{array}$ & $\begin{array}{c}\text { Öncel et } \\
\text { al. } \\
(2016)\end{array}$ \\
\hline PBR materials & & 1 & & & & & 1 & \\
\hline PBR flat panel thickness & & 1 & & & & & 1 & \\
\hline Temperature & 1 & 1 & 1 & 1 & & & 1 & \\
\hline Light intensity & 1 & I & 1 & & & 1 & 1 & 1 \\
\hline $\begin{array}{l}\text { Building orientation and position } \\
\text { lluminated areas (building mass } \\
\text { and exposed surface area) }\end{array}$ & & & & & 1 & 1 & 1 & 1 \\
\hline $\begin{array}{l}\text { Water intake and nutrient supply } \\
\text { Integrated maintenance area (raise } \\
\text { platform, biomass collection point } \\
\text { and energy management system) }\end{array}$ & I & I & l & 1 & 1 & I & I & I \\
\hline $\begin{array}{l}\text { Integrated air flow system } \\
\text { Building facade aesthetic }\end{array}$ & I & 1 & 1 & i & 1 & 1 & i & \\
\hline
\end{tabular}

(Source: Author)

\subsubsection{Materials}

Photobioreactor (PBR) using transparent vertical tubings such as glass or acrylic, allows the penetration of light for autotrophic microalgae cultivation (Zhang, 2015). Qiu (2014) added that PBRs could be made from different transparent materials, but the choice of the material determines the durability of the PBR. Acrylic tubing and stacked layers of glass provide longer lifespan as compared to other transparent materials.

\subsubsection{Thickness}

In designing the PBR panels, the recommended size should be less than $1.5 \mathrm{~m}$ in height by $0.10 \mathrm{~m}$ in width with the thickness of a maximum of 5 to $6 \mathrm{~cm}$ to allow for light penetration (Fernandez et al., 2013). According to Slegers et al., (2014), the vertical panels should be set apart $0.5 \mathrm{~m}$ to maintain its efficiency, and it can also be arranged vertically or horizontally for better efficiency of the site.

\subsubsection{Temperature}

Temperature influences the biochemical process of microalgae. Low temperature reduces carbon assimilation activity while extremely high temperature decreases photosynthesis by inactivating the photosynthetic proteins, thus reducing the cell size and respiration. According to Singh and Singh (2015), the optimal temperature for microalgae cultivation is between $20-30{ }^{\circ} \mathrm{C}$, but it can still tolerate higher temperatures with a lower productivity rate.

\subsubsection{Light intensity}

Microalgae require light as an energy source to convert the absorbed water and carbon dioxide into biomass through photosynthesis. According to Krzemińska et al. (2014), light duration and intensity directly affect photosynthesis and influence the biochemical composition of microalgae and biomass yield. Microalgae cannot grow efficiently in a condition with very low or very high light intensities (Mata et al., 2010). According to Bazdar et al. (2018), the optimum range for light intensity in microalgae cultivation is between 5000 to $6500 \mathrm{~lx}$, but artificial lighting of $10000 \mathrm{~lx}$ may boost the productivity rate even higher.

\subsubsection{Building orientation and position}

The building orientation and position influence the interception of solar radiation. According to Sierra et al. (2008), the placement of PBRs at the east and west orientation provides higher efficiency for latitudes above $35^{\circ} \mathrm{N}$ while the north and south orientation is the preferred position for latitudes under $35^{\circ} \mathrm{N}$.

\subsubsection{Illuminated area (building mass and exposed surface area)}

Surface area to volume ratio influences the productivity of biomass in microalgae cultivation. The use of closed-looped PBRs on large surfaces will increase the exposure to sunlight, thus increasing the productivity rate of microalgae biomass.

\subsubsection{Water intake and nutrient supply}

Microalgae can bloom in any water sources. The cultivation of microalgae requires nitrogen and phosphorus as its major nutrients with wastewater as an optimum source for these required nutrients (Khan et al., 2018). 


\subsubsection{Integrated maintenance area (Raise Platform, biomass collection point and energy management system)}

According to Wilkinson et al. (2018), the PBR glazing panels and pipes with valves require cleaning and periodic replacement to maintain its lifespan and durability. To ensure its continued optimum performance, the closed-looped PBRs require a raised platform for ease of maintenance.

\subsubsection{Integrated airflow system}

Carbon dioxide is the main source for microalgae cultivation. One (1) tonne of microalgae biomass requires an approximate of 1.8 tonnes of carbon dioxide. In ensuring a sufficient supply of carbon dioxide, the carbon dioxide scrubbing system is used as an alternative to natural means to transport and store the carbon dioxide. This system requires an integrated wind turbine to generate electricity for operation.

\subsubsection{Building facade aesthetic}

According to Khan, M. I., Shin, J. H., \& Kim, J. D. (2018), in recent years, microalgae have gained interest from around the world, due to their potential application in renewable and sustainable energy. However, many people are still not aware of this natural renewable resources as even considered them as pond scum. According to Pagliolico et al. ( 2017 ), the integration of PBRs in the building facades affects the transparency and visibility of the building. While the placement of microalgae PBRs must take into consideration the efficiency of energy generation, the microalgae can create a dynamic architectural configuration through the seasonally varying activity of bioenergy production and the rising movement of bubbles through the PBRs.

\subsection{The Tropical Climate in Malaysia}

The light intensity in Malaysia is shown in Figure 2. The annual mean temperature in Malaysia is $26.4^{\circ} \mathrm{C}$, with an average daily maximum temperature of $34^{\circ} \mathrm{C}$ and the average daily minimum at $23^{\circ} \mathrm{C}$ (Jamaludin et al., 2015). According to MS1525:2014, indoor design condition temperature should be between $24 \mathrm{C}$ to $26 \mathrm{C}$ to ensure thermal comfort for the building occupants. However, research by Qahtan (2019) indicates that indoor air temperature of building in Malaysia varies from 26.4C to 27.6C. Therefore, the use of any building cooling requirements is highly recommendable to ensure thermal comfort is reached through the use of low e-glass, double skin facade or even the proposed microalgae photobioreactor.

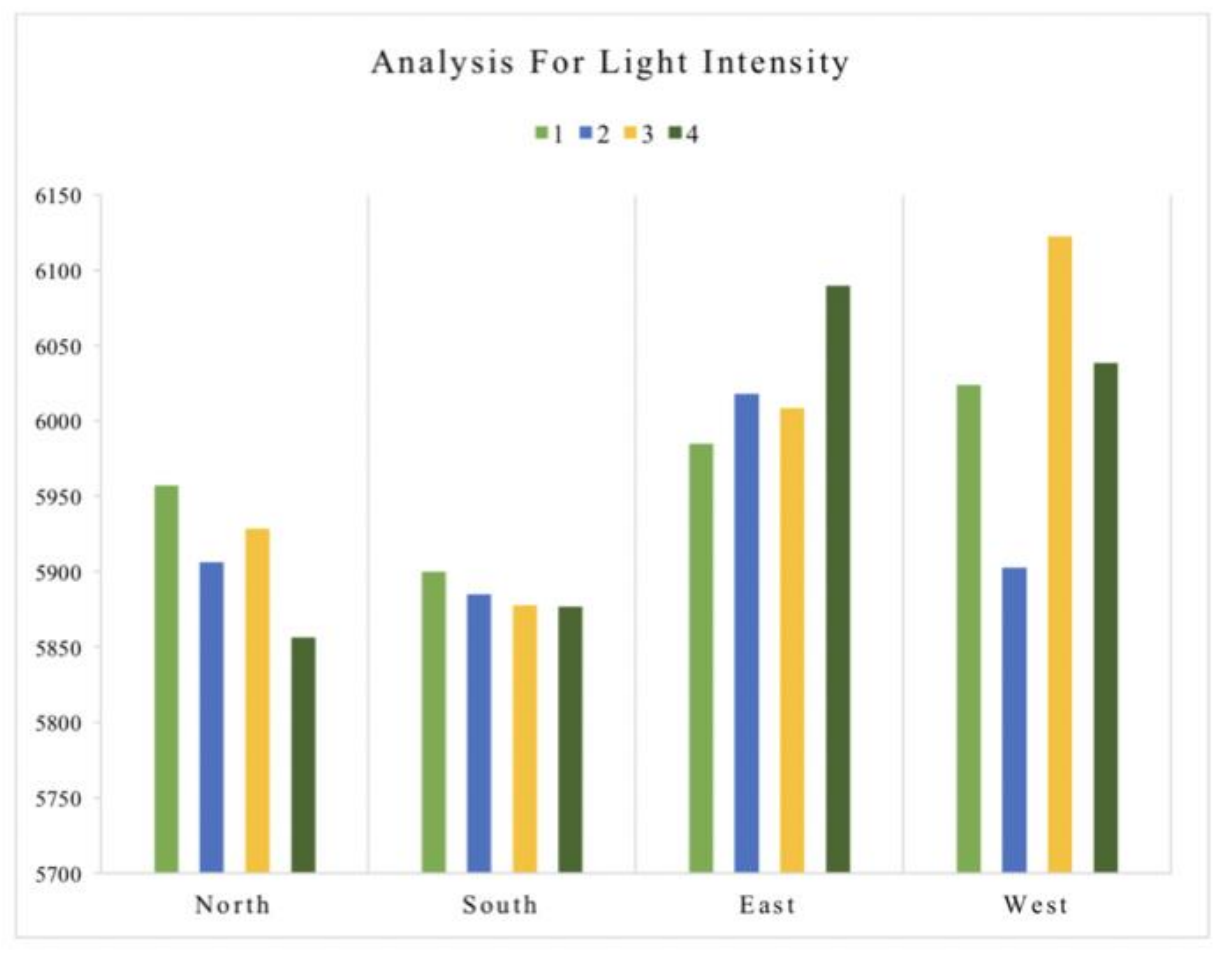

Fig. 2: Analysis of Light Intensity (Source: Author)

\subsection{Heat Gain and Human Behaviour}

According to Qathan (2019), despite the decrease in outdoor air temperature, indoor air temperature can remain high due to the fact that heat is trapped indoor when direct solar radiation infiltrates the glazing. A typical clear float glass when it is wrongly oriented and designed will pose difficulty in controlling direct solar heat gain into the building. Furthermore, the inexistence of building cooling requirements can implicate the thermal comfort condition inside the building. $\mathrm{Zr}$ and Mochtar (2013) said that without using a mechanical system in building such as air conditioning and fan for thermal control, the building conditions could disadvantageously affect the occupants' health as well as productivity. 


\subsection{Methodology}

The research is divided into four (4) main stages, as highlighted in figure 2.

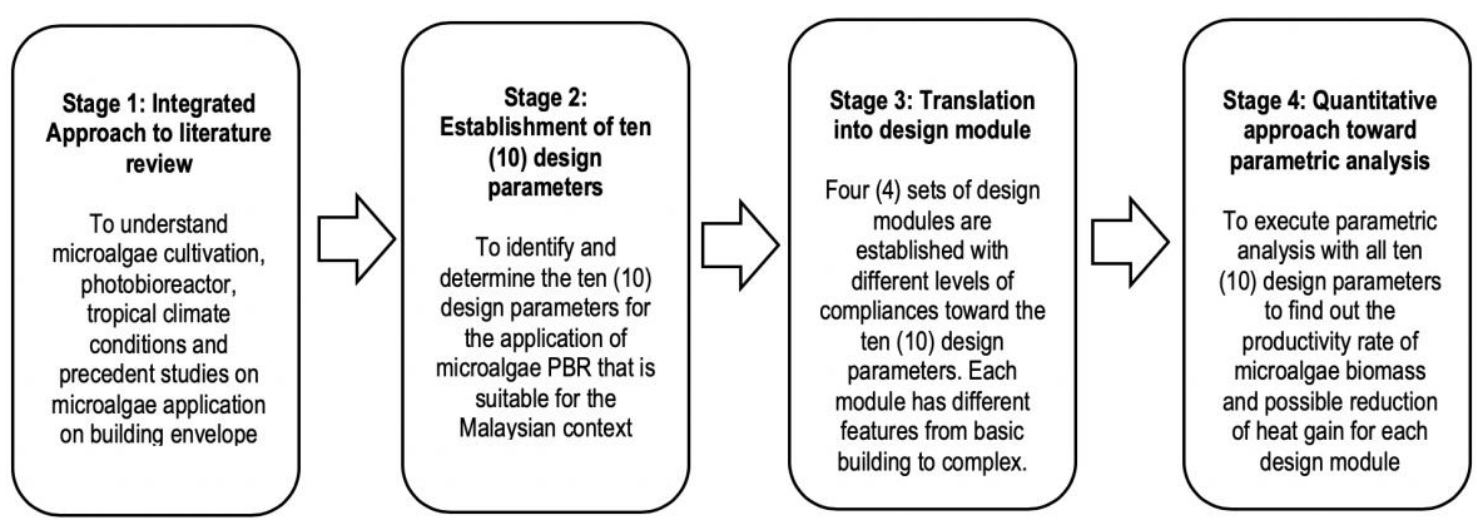

Fig. 3: The research direction

(Source: Author)

\subsection{Stage 1 - Integrated Approach To Literature Review}

Stage 1 involves the content analysis of microalgae cultivation, photobioreactor (PBR), tropical climate conditions and provides a comparative analysis of the precedent studies and determines the level of application of microalgae PBRs on existing building envelopes.

\subsection{Stage 2 - Establishment of ten (10) design parameters}

Stage 2 identify and determine the ten (10) design parameters for the application of microalgae PBR in the tropical climate building envelope. The establishment of the design parameters are according to the suitability of the Malaysian context and will be used in stage 3 and 4 . The ten (10) established design parameters are as follows:

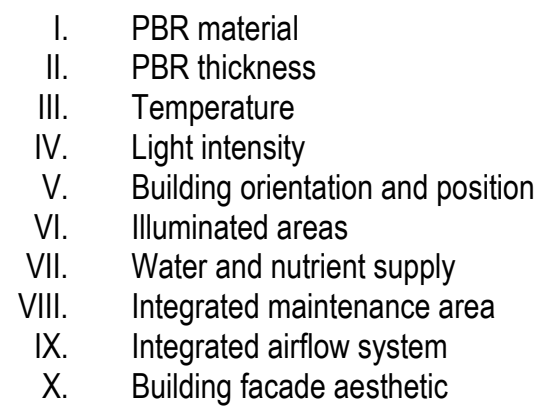

\subsection{Stage 3 - Translation into Design Module}

Stage 3 involves the establishment of four (4) sets of building design modules with different complexity levels of application for microalgae photobioreactor on the building envelope. Each module complies with the different aspects of the ten (10) design parameters as stipulated in figure 3. The design modules are created using BIM modelling software that consists of the followings:

I. Module $\mathrm{A}$ is a basic conventional building with a typical configuration of building block

II. Module $B$ is an extended rectangular building block that spread out to have larger illuminated areas

III. Module $\mathrm{C}$ is almost similar to module $\mathrm{B}$ with an addition of a building core system at each building block

IV. Module $D$ is a complex building with a high level of configuration and compliances to suit the implementation of microalgae PBR in its building envelope 
Module A

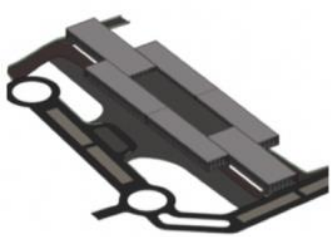

Module B

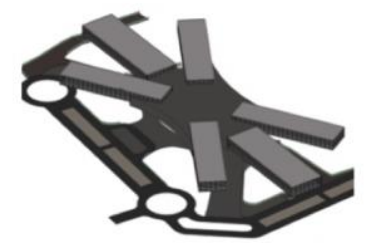

Module C

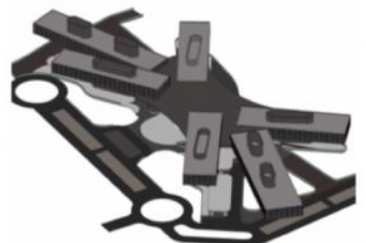

Module D

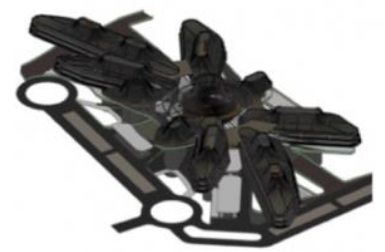

Fig. 4: Design Modules (Source: Author)

\subsection{Stage 4 - Quantitative Approach Through Parametric Analysis}

Stage 4 applies the use of parametric analysis through modelling tools, daylight simulation software and formula to explore the possibilities and potentialities of the design modules established in stage 3. The Durian Artificial SkyDome simulation and the BIM modelling software will help to measure the productivity rate of microalgae biomass and possible reduction of heat gain according to the selected measurements as mentioned in 3.4.3.

\subsubsection{Daylight simulation using Durian Artificial SkyDome}

The Durian Artificial SkyDome is used for design parameters 3 to 6 . It provides generic modelling of site context through an urban simulation and establishes data of light intensity at different points of the site, as seen in figure 4 and figure 5 . This will help the configuration of the design module to spread out according to the light intensity readings on site.

\subsubsection{Building modelling using BIM software}

The BIM modelling software is applied in parameters 7 to 10. This software provides a series of building module with emulated settings to match the real-time environment. Each design module will have a different level of complexity and configuration applied, but the floor area will remain consistent at 8000 sqm.

\subsubsection{The Measuring Method for Productivity Rate of Microalgae Biomass and Heat Gain Reduction}

Pruvost (2014), suggests that the PBR facade can produce about $200 \mathrm{~g}$ per $\mathrm{m} 3$ each day of dry biomass. This is supported by Ismail and Al Obaidi (2018) that uses the same formula of $200 \mathrm{~g} / \mathrm{m} 3 /$ day to calculate microalgae biomass in their study on microalgae facade in the tropical climate. In addition, Ismail and Al Obaidi (2018) also added the $\mathrm{w} / \mathrm{m} 2 /$ percentage formula to calculate the possible reduction of heat gain due to solar radiation in their findings.

\subsection{Limitation of Study}

The urban simulation is conducted at a sewerage plantation lake which is a potential option for microalgae growth and might differ in terms of its growing capabilities in other urban site conditions. Besides that, although the BIM Modelling Software provides functions to perform the building energy analysis such as thermal comfort, there is a limitation in terms of the application of the photobioreactor (PBR) panels due to the restrictions of the specific components to conduct the simulation. Therefore, the study will only focus on the existing measurement formulas to determine the possible reduction of heat gain through the production of algae biomass in the PBR panels.

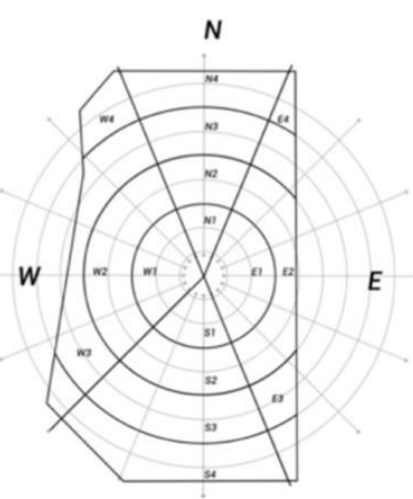

$S$

Fig. 5: Plan view of the site (Source: Author)

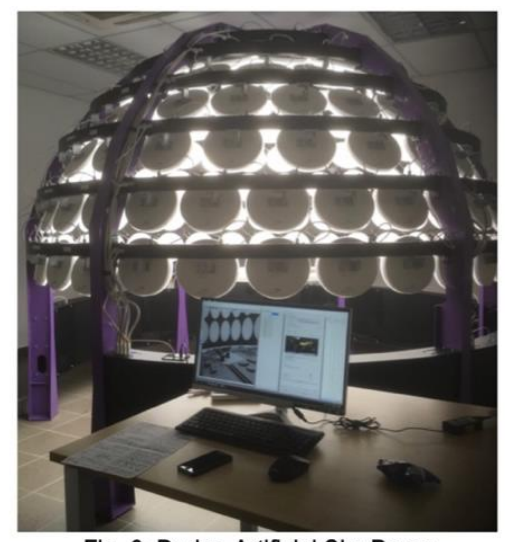

Fig. 6: Durian Artificial Sky Dome (Source: Author)

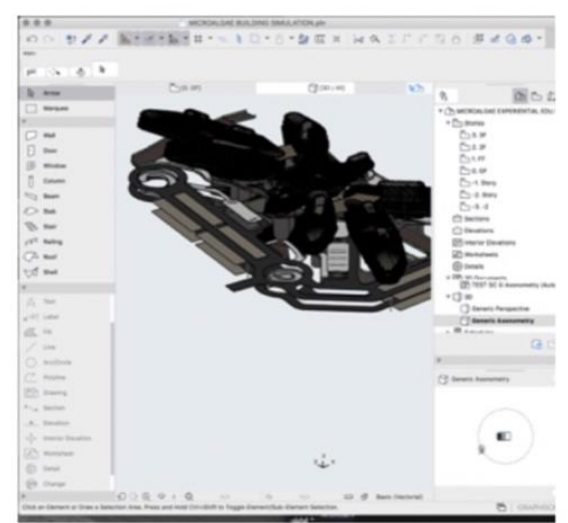

Fig. 7: BIM Modelling Software (Source: Author) 


\subsection{Findings}

4.1 The level of application of microalgae PBR on building envelopes

Table 2 illustrates the different level of application of microalgae PBR on building envelopes in four (4) different building types.

Table 2: Comparison of precedent studies

\begin{tabular}{|c|c|c|c|c|}
\hline Case study & $\begin{array}{c}\text { BIQ Building, Hamburg, } \\
\text { Germany }\end{array}$ & $\begin{array}{c}\text { Process Zero, Los Angeles, } \\
\text { California, USA }\end{array}$ & $\begin{array}{l}\text { Green Loop Tower, } \\
\text { Chicago, Illinois }\end{array}$ & In Vivo, Paris,France \\
\hline $\begin{array}{l}\text { PBR } \\
\text { integration } \\
\text { into } \\
\text { building } \\
\text { envelope }\end{array}$ & 51 & & 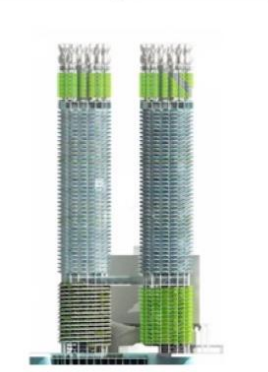 & 4 \\
\hline Building type & New and retrofitted building & Retrofitted building & Retrofitted building & New and retrofitted building \\
\hline $\begin{array}{l}\text { PBR } \\
\text { installation } \\
\text { and } \\
\text { appearances }\end{array}$ & $\begin{array}{l}\text { Flat panel PBRs are installed } \\
\text { on two sides which are the } \\
\text { southeast and southwest } \\
\text { facades. It also serves as } \\
\text { shading and insulation from } \\
\text { sound, heat, and cold. }\end{array}$ & $\begin{array}{l}\text { Tubular PBR panels cover } 4 \\
\text { sides of the building facades } \\
\text { which are the north, south, east } \\
\text { and west. It surrounds the } \\
\text { whole building envelopes and } \\
\text { acts as green façade. }\end{array}$ & $\begin{array}{l}\text { Helical PBRs are wrapped } \\
\text { around the entire perimeter } \\
\text { of the two cylinder-shaped } \\
\text { building tower creating a } \\
\text { continuous looping of green } \\
\text { cycle. }\end{array}$ & $\begin{array}{l}\text { Microalgae biofacade is } \\
\text { installed at the third building } \\
\text { block that are facing the main } \\
\text { road while providing direct } \\
\text { sunlight shading and biological } \\
\text { aesthetic display. }\end{array}$ \\
\hline $\begin{array}{l}\text { PBR } \\
\text { Specification }\end{array}$ & $\begin{array}{l}129 \text { PBRs are installed on the } \\
\text { southeast and southwest } \\
\text { facades. Each panel measures } \\
2.5 \mathrm{~m} \times 0.7 \mathrm{~m} \text { with a thickness } \\
\text { of } 0.8 \mathrm{~m} \text {. }\end{array}$ & $\begin{array}{l}\text { The PBRs cover } 2500 \mathrm{ft}^{2} \text { of the } \\
\text { GSA building envelope with a } \\
\text { modular network of transparent } \\
\text { glass tubing. }\end{array}$ & $\begin{array}{l}\text { A modular system of algal } \\
\text { tubes is coiled around the } \\
\mathrm{CO}_{2} \text { scrubbing units in a } \\
\text { helical manner on the tops } \\
\text { of both towers. }\end{array}$ & $\begin{array}{l}\text { This new generation facade, } \\
\text { operated by AlgoSource, will } \\
\text { house microalgae cultures } \\
\text { within biological solar panels. }\end{array}$ \\
\hline PBR design & Flat vertical panel PBR & $\begin{array}{c}\text { Modular tube panel PBR } \\
\text { membrane }\end{array}$ & Helical tube PBR & $\begin{array}{l}\text { Flat bio facade panel / } \\
\text { biological solar panels }\end{array}$ \\
\hline Air flow cycle & $\begin{array}{l}\text { From bio-gas fueled microchip } \\
\text { on site, a membrane } \\
\text { technology and saturation } \\
\text { device are used to provide the } \\
\text { water circuit with } \mathrm{CO}_{2} \text { stream }\end{array}$ & $\begin{array}{l}\text { The system derives its } \mathrm{CO}_{2} \\
\text { from nearby freeway on site to } \\
\text { central feeding vessel to allow } \\
\text { algae to absorb much of the } \\
\text { carbon }\end{array}$ & $\begin{array}{l}\text { Air is captured, harvested } \\
\text { and filtered by a wind } \\
\text { turbine then oxygen is } \\
\text { released to the city and } \\
\text { absorbing } \mathrm{CO}^{2} \text { by the } \\
\text { scrubbing units to feed the } \\
\text { algae PBR. }\end{array}$ & $\begin{array}{l}\text { The system derives its } \mathrm{CO}_{2} \\
\text { from the adjacent main road } \\
\text { right next to the building side }\end{array}$ \\
\hline $\begin{array}{l}\text { Source of } \\
\text { water and } \\
\text { nutrients }\end{array}$ & $\begin{array}{l}\text { The culture medium enriched } \\
\text { with nitrogen, phosphorus and } \\
\text { trace elements as nutrients }\end{array}$ & $\begin{array}{l}\text { Waste water of the building is } \\
\text { the source of water. The black } \\
\text { water of the building is } \\
\text { processed to be a source of } \\
\text { nutrients }\end{array}$ & $\begin{array}{l}\text { All waste water of Marina } \\
\text { City inhabitants are } \\
\text { processed to be reused } \\
\text { either in the WCs or to } \\
\text { irrigate vertical farming }\end{array}$ & $\begin{array}{l}\text { Creation of three different type } \\
\text { of building purpose that able to } \\
\text { provide basic supplies (water / } \\
\text { waste / nutrients) to each other }\end{array}$ \\
\hline $\begin{array}{l}\text { Purpose of } \\
\text { installing } \\
\text { PBR }\end{array}$ & $\begin{array}{l}\text { PBRs produce heat and } \\
\text { biomass. The bioreactor } \\
\text { facades capable in removing a } \\
\text { high amount of } \mathrm{CO}^{2} \text { by using } \\
\text { flue gas delivered in the gas } \\
\text { burner to produce biomass in } \\
\text { the PBRs. }\end{array}$ & $\begin{array}{l}\text { The system is renewable } \\
\text { energy systems that includes a } \\
\text { thin photovoltaic facade } \\
\text { system, rooftop photovoltaics, } \\
\text { integrated solar thermal panel } \\
\text { and an innovative algae } \\
\text { system. }\end{array}$ & $\begin{array}{l}\text { It is mainly to showcase } \\
\text { Algae potential connection } \\
\text { with new emerging green } \\
\text { technologies, to create a } \\
\text { whole new } \mathrm{CO}^{2} \text { scrubbing } \\
\text { integrated system. }\end{array}$ & $\begin{array}{l}\text { It provides valuable biomass } \\
\text { for medical research and } \\
\text { productive biofacade will allow } \\
\text { building to use the heat } \\
\text { collected by the PBRs for } \\
\text { domestic hot water and } \\
\text { heating. }\end{array}$ \\
\hline $\begin{array}{l}\text { Location of } \\
\text { Building } \\
\text { Services }\end{array}$ & $\begin{array}{l}\text { The boreholes consist of wells } \\
\text { located under the building } \\
\text { subsoil. Central building } \\
\text { management system (BMS) } \\
\text { manages all the processes } \\
\text { necessary to operate the PBR } \\
\text { facade }\end{array}$ & $\begin{array}{l}\text { It works under the ground level } \\
\text { and connected with recovery } \\
\text { units to produce power while } \\
\text { minimize consumption. }\end{array}$ & $\mathrm{Na}$ & $\mathrm{Na}$ \\
\hline
\end{tabular}

(Source: Author)

According to table 2, each building has different methods of application on the installation of the microalgae photobioreactor (PBR), particularly on the design of the PBR. From the analysis of the comparisons, the BIQ building has the most significant level of application due to the usage of the flat vertical panel PBR that is flexible and suitable for its climate. 


\subsection{The establishment of the design parameters}

The information gathered from Table 1 are extracted and extrapolated into ten (10) design parameters for microalgae PBRs on building envelopes based on its suitability for the Malaysian context, as shown in Table 3.

Table 3: Brief description of the design parameters

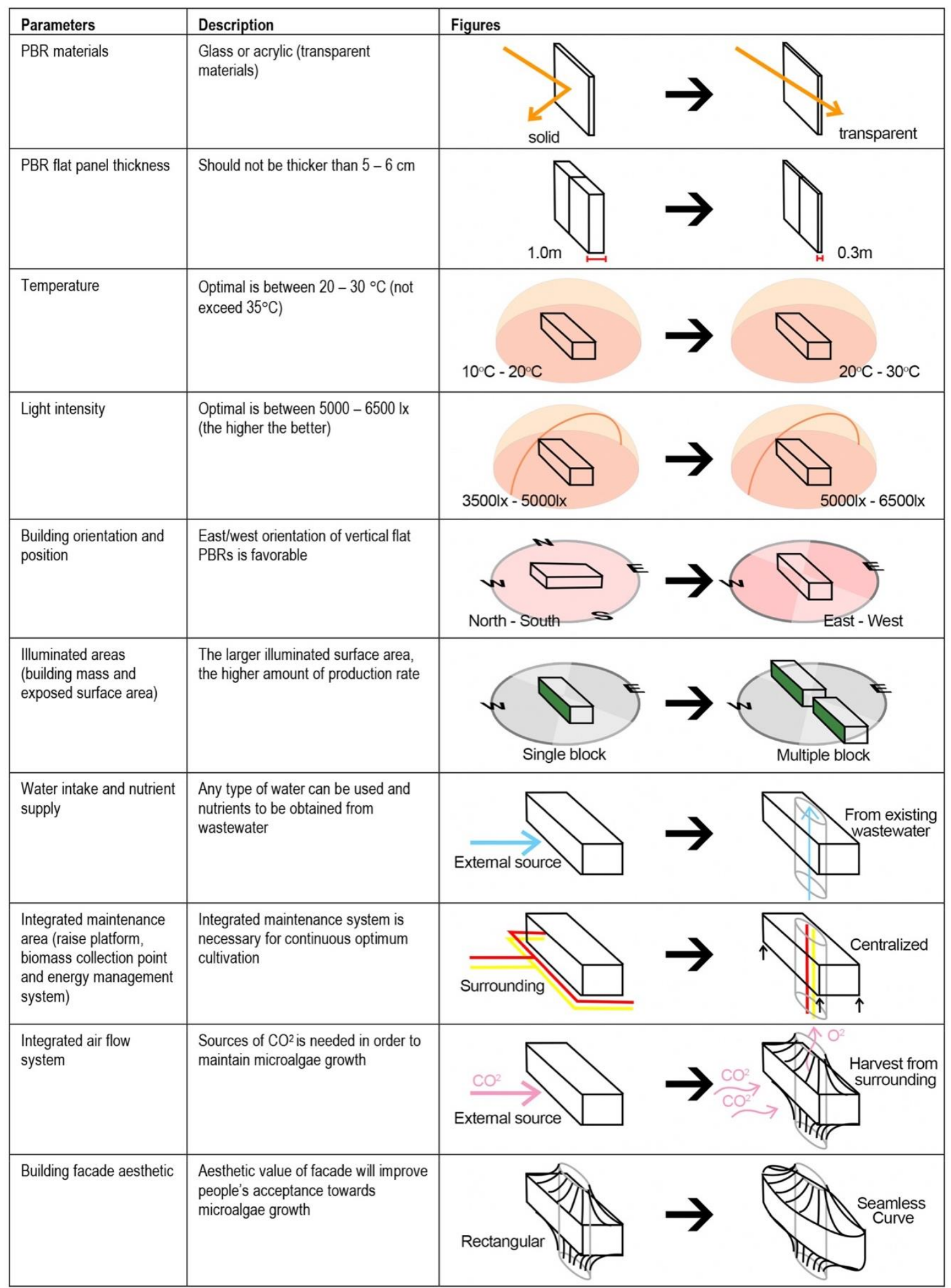

(Source: Author)

According to table 3 , there are ten (10) design parameters that can be applied for building envelopes in Malaysia. These parameters are ranging from the physical design of the microalgae PBR to the mechanical considerations and its aesthetical values. 


\subsection{Design parameters vs Design Modules}

Table 4 to 7 illustrates the different applications of the established design parameters in four (4) different design modules.

\section{Design Module A}

Table 4: The established design parameters for building facade with integrated microalgae PBR for Design Module A

\begin{tabular}{|c|c|c|c|}
\hline $\begin{array}{l}\text { Design } \\
\text { Parameters }\end{array}$ & Diagrammatic Design Module & Application of parameters on building design module & $\begin{array}{l}\text { Compliance } \\
\text { with the } \\
\text { parameters }\end{array}$ \\
\hline Materials & & Usage of $4 \mathrm{~m} \times 1 \mathrm{~m} \times 0.3 \mathrm{~m}$ rectangular tank with transparent glass & Yes \\
\hline Thickness & & The thickness of the transparent glass panel is $0.3 \mathrm{~m}$ & Yes \\
\hline Temperature & & Average temperature of $23 \mathrm{C}$ to $31 \mathrm{C}$ on site throughout the year & Yes \\
\hline Light intensity & & $\begin{array}{l}\text { Sufficient amount of sunlight from 5500lux to 6500lux due to the hot } \\
\text { and humid climate }\end{array}$ & Yes \\
\hline $\begin{array}{l}\text { Building } \\
\text { Orientation }\end{array}$ & & $\begin{array}{l}\text { Most part of the building are located on the north and south region of } \\
\text { the site which have lower illuminated area }\end{array}$ & No \\
\hline Illuminated Area & & Building surface areas that are exposed to the sunlight is $800 \mathrm{sqm}$ & No \\
\hline $\begin{array}{l}\text { Water And } \\
\text { Nutrient Supply }\end{array}$ & & Regular water intake and nutrient supply from external source & No \\
\hline $\begin{array}{l}\text { Integrated } \\
\text { Maintenance } \\
\text { Area }\end{array}$ & & $\begin{array}{l}\text { Exposed maintenance area that are surrounding the building } \\
\text { envelope }\end{array}$ & No \\
\hline $\begin{array}{l}\text { Integrated Air } \\
\text { Flow System }\end{array}$ & & No source of carbon dioxide & No \\
\hline $\begin{array}{l}\text { Building Facade } \\
\text { Aesthetic }\end{array}$ & & Bulky and closed rectangular building block & No \\
\hline
\end{tabular}

(Source: Author) 


\section{Design Module B}

Table 5: The established design parameters for building facade with integrated microalgae PBR for Design Module B

\begin{tabular}{|c|c|c|c|}
\hline $\begin{array}{l}\text { Design } \\
\text { Parameters }\end{array}$ & Diagrammatic Design Module & Application of parameters on building design module & $\begin{array}{l}\text { Compliance } \\
\text { with the } \\
\text { parameters }\end{array}$ \\
\hline Materials & & Usage of $4 \mathrm{~m} \times 1 \mathrm{~m} \times 0.3 \mathrm{~m}$ rectangular tank with transparent glass & Yes \\
\hline Thickness & & The thickness of the transparent glass panel is $0.3 \mathrm{~m}$ & Yes \\
\hline Temperature & & Average temperature of $23 \mathrm{C}$ to $31 \mathrm{C}$ on site throughout the year & Yes \\
\hline Light intensity & & $\begin{array}{l}\text { Sufficient amount of sunlight from 5500lux to } 6500 \text { lux due to the hot } \\
\text { and humid climate }\end{array}$ & Yes \\
\hline $\begin{array}{l}\text { Building } \\
\text { Orientation }\end{array}$ & & $\begin{array}{l}\text { Most part of the building are located on the east and west region of } \\
\text { the site which have higher illuminated area }\end{array}$ & Yes \\
\hline Illuminated Area & & Building surface areas that are exposed to the sunlight is 1000 sqm & Yes \\
\hline $\begin{array}{l}\text { Water And } \\
\text { Nutrient Supply }\end{array}$ & & Regular water intake and nutrient supply from external source & No \\
\hline $\begin{array}{l}\text { Integrated } \\
\text { Maintenance } \\
\text { Area }\end{array}$ & & $\begin{array}{l}\text { Exposed maintenance area that are surrounding the building } \\
\text { envelope }\end{array}$ & No \\
\hline $\begin{array}{l}\text { Integrated Air } \\
\text { Flow System }\end{array}$ & & No source of carbon dioxide & No \\
\hline $\begin{array}{l}\text { Building Facade } \\
\text { Aesthetic }\end{array}$ & & Spread out and extended rectangular building block & No \\
\hline
\end{tabular}

(Source: Author) 


\section{Design Module C}

Table 6: The established design parameters for building facade with integrated microalgae PBR for Design Module C

\begin{tabular}{|c|c|c|c|}
\hline $\begin{array}{l}\text { Design } \\
\text { Parameters }\end{array}$ & Diagrammatic Design Module & Application of parameters on building design module & $\begin{array}{l}\text { Compliance } \\
\text { with the } \\
\text { parameters }\end{array}$ \\
\hline Materials & & Usage of $4 \mathrm{~m} \times 1 \mathrm{~m} \times 0.3 \mathrm{~m}$ rectangular tank with transparent glass & Yes \\
\hline Thickness & & The thickness of the transparent glass panel is $0.3 \mathrm{~m}$ & Yes \\
\hline Temperature & & Average temperature of $23 \mathrm{C}$ to $31 \mathrm{C}$ on site throughout the year & Yes \\
\hline Light intensity & & $\begin{array}{l}\text { Sufficient amount of sunlight from 5500lux to } 6500 \text { lux due to the hot } \\
\text { and humid climate }\end{array}$ & Yes \\
\hline $\begin{array}{l}\text { Building } \\
\text { Orientation }\end{array}$ & & $\begin{array}{l}\text { Most part of the building are located on the east and west region of } \\
\text { the site which have higher illuminated area }\end{array}$ & Yes \\
\hline Illuminated Area & & Building surface areas that are exposed to the sunlight is $1200 \mathrm{sqm}$ & Yes \\
\hline $\begin{array}{l}\text { Water And } \\
\text { Nutrient Supply }\end{array}$ & & $\begin{array}{l}\text { Centralized building core with integrated filtering, pumping and riser } \\
\text { system for collecting water and nutrient supply from the lake }\end{array}$ & Yes \\
\hline $\begin{array}{l}\text { Integrated } \\
\text { Maintenance } \\
\text { Area }\end{array}$ & & Raise platform with biomass collection point at the building core & Yes \\
\hline $\begin{array}{l}\text { Integrated Air } \\
\text { Flow System }\end{array}$ & & $\begin{array}{l}\text { Air is captured and carbon dioxide is harvested for microalgae } \\
\text { growth }\end{array}$ & No \\
\hline $\begin{array}{l}\text { Building Facade } \\
\text { Aesthetic }\end{array}$ & & $\begin{array}{l}\text { Spread out and extended rectangular building block with different } \\
\text { platform level }\end{array}$ & No \\
\hline
\end{tabular}




\section{Design Module D}

Table 7: The established design parameters for building facade with integrated microalgae PBR for Design Module D

\begin{tabular}{|c|c|c|c|}
\hline $\begin{array}{l}\text { Design } \\
\text { Parameters }\end{array}$ & Diagrammatic Design Module & Application of parameters on building design module & $\begin{array}{l}\text { Compliance } \\
\text { with the } \\
\text { parameters }\end{array}$ \\
\hline Materials & & Usage of $4 \mathrm{~m} \times 1 \mathrm{~m} \times 0.3 \mathrm{~m}$ rectangular tank with transparent glass & Yes \\
\hline Thickness & & The thickness of the transparent glass panel is $0.3 \mathrm{~m}$ & Yes \\
\hline Temperature & & Average temperature of $23 \mathrm{C}$ to $31 \mathrm{C}$ on site throughout the year & Yes \\
\hline Light intensity & & $\begin{array}{l}\text { Sufficient amount of sunlight from 5500lux to } 6500 \text { lux due to the hot } \\
\text { and humid climate }\end{array}$ & Yes \\
\hline $\begin{array}{l}\text { Building } \\
\text { Orientation }\end{array}$ & & $\begin{array}{l}\text { Most part of the building are located on the east and west region of } \\
\text { the site which have higher illuminated area }\end{array}$ & Yes \\
\hline Illuminated Area & & Building surface areas that are exposed to the sunlight is 1500 sqm & Yes \\
\hline $\begin{array}{l}\text { Water And } \\
\text { Nutrient Supply }\end{array}$ & & $\begin{array}{l}\text { Centralized building core with integrated filtering, pumping and riser } \\
\text { system for collecting water and nutrient supply from the lake }\end{array}$ & Yes \\
\hline $\begin{array}{l}\text { Integrated } \\
\text { Maintenance } \\
\text { Area }\end{array}$ & & Raise platform with biomass collection point at the building core & Yes \\
\hline $\begin{array}{l}\text { Integrated Air } \\
\text { Flow System }\end{array}$ & & $\begin{array}{l}\text { Air is captured and carbon dioxide is harvested for microalgae } \\
\text { growth and oxygen is released back to the surrounding }\end{array}$ & Yes \\
\hline $\begin{array}{l}\text { Building Facade } \\
\text { Aesthetic }\end{array}$ & & $\begin{array}{l}\text { Spread out and extended building block with different platform level. } \\
\text { Each block have a seamless parametric and fluid structure }\end{array}$ & Yes \\
\hline
\end{tabular}

(Source: Author)

According to table 4 to 7 , all modules have similar applications of the established design parameters, but each module possesses a different level of compliance. Module A managed to comply with $40 \%$ of the parameters because it only covers the four (4) basic requirements while Module $B$ and $C$ are higher with $60 \%$ and $80 \%$ compliance respectively. Module D applies all the ten (10) design parameters suggested within this study and achieve the highest level of compliance in this parametric analysis. 


\subsection{Discussion}

Table 8: Microalgae biomass productivity rate and possible reduction of heat gain

\begin{tabular}{|c|c|c|c|}
\hline $\begin{array}{c}\text { Design } \\
\text { Module }\end{array}$ & $\begin{array}{c}\text { Compliance with the } \\
\text { parameters }\end{array}$ & $\begin{array}{c}\text { Productivity rate of microalgae biomass in } \\
\begin{array}{c}\text { PBR } \\
\left(\mathbf{2 0 0 g} / \mathbf{m}^{3} / \text { day) }\right.\end{array}\end{array}$ & $\begin{array}{c}\text { Possible reduction of heat gain due to solar } \\
\text { radiation } \\
\text { (w/m2 / percentage) }\end{array}$ \\
\hline A & $40 \%$ & $240 \mathrm{~m}^{3}=48 \mathrm{~kg}$ & $17.96 \%$ \\
\hline B & $60 \%$ & $300 \mathrm{~m}^{3}=60 \mathrm{~kg}$ & $26.94 \%$ \\
\hline C & $80 \%$ & $360 \mathrm{~m}^{3}=72 \mathrm{~kg}$ & $35.92 \%$ \\
\hline D & $100 \%$ & $450 \mathrm{~m}^{3}=90 \mathrm{~kg}$ & $44.9 \%$ \\
\hline
\end{tabular}

(Source: Author)

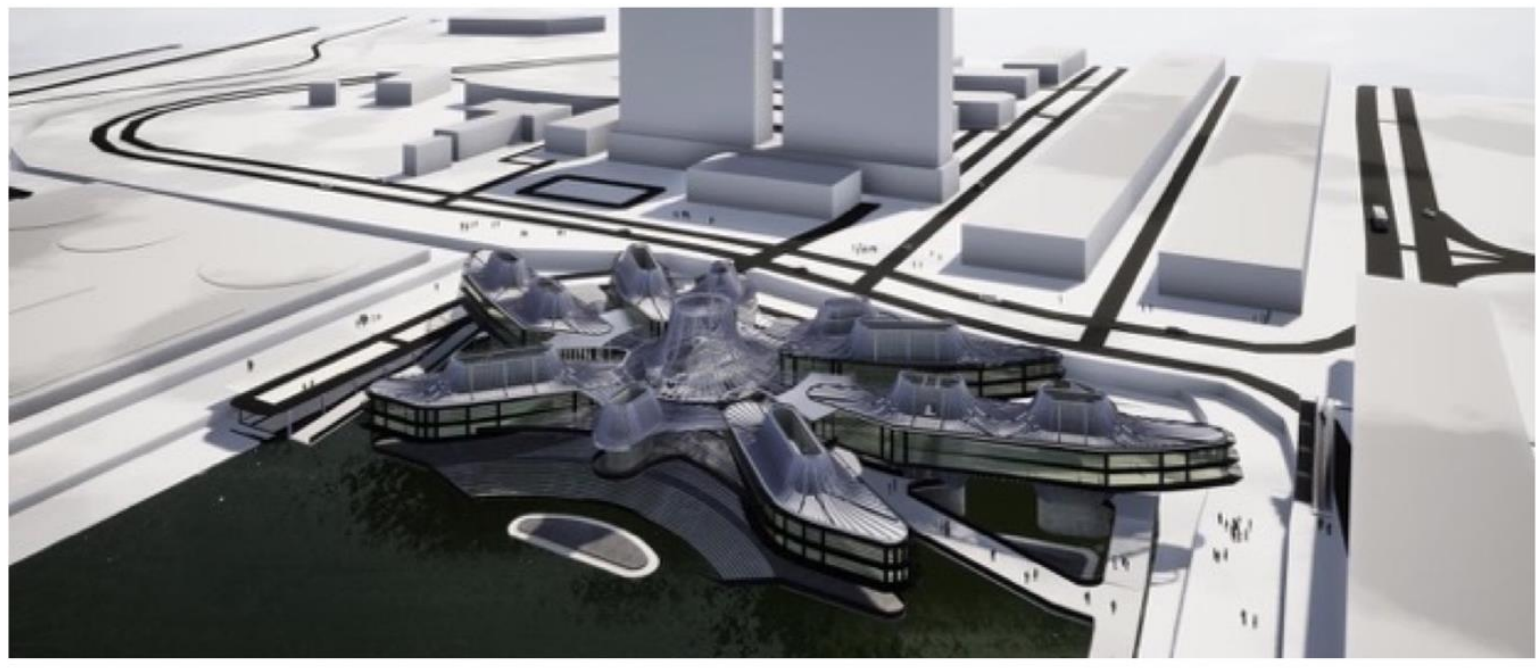

Figure 8: Aerial view of Module D (Source: Author)

Based on table 2, the comparative study between the four (4) selected buildings provides further understanding for a useful application of microalgae photobioreactor (PBR) on building envelopes. This understanding contributes to the establishment of the ten (10) design parameters, as mentioned in table 3. The next stage involves the translation of the established design parameters into four (4) types of design exploration modules that comply with the different sets of parameters and test using the quantitative parametric analysis.

Table 8 summarizes the efficiency score for all design modules. The findings show that all four design modules comply with the four (4) basic requirements for microalgae cultivation which are the materials used, panel thickness, temperature, and light intensity. Module A has the lowest microalgae biomass productivity rate as compared to the other three (3) modules because it only complies with the basic requirements needed for microalgae growth. The east and west building orientation is one of the major determining factors that influence the efficiency of biomass productivity. This strategy is applied in modules $B, C$, and $D$, with an increase of the illuminated surface area to utilise the exposure to the sun.

The integrated maintenance area and the centralised building core with integrated filtering, pumping and riser system, which is seen in module $C$ and $D$ allows the collection of water and nutrient from the sewerage plantation lake. This method reduces the regular water intake and nutrient supply from the external source. The integrated services together with the airflow system as proposed in module $\mathrm{D}$, allow efficient regular maintenance and is proven to be more effective in improving the microalgae biomass productivity rate. Overall, the existence of an integrated maintenance area and airflow system in the building will further ensure the efficiency of microalgae cultivation. Furthermore, to avoid the bulky and unattractive appearance, the design of the microalgae PBR follow a seamless curve which also helps to increase the size of the illuminated surface area. The findings in table 8 indicate that module $\mathrm{D}$ has the best microalgae biomass productivity rate and reduction in building heat gain as it complies with the ten (10) design parameters suggested within this study. In the parametric analysis, it is evident that the suggested design parameters are essential for the application of microalgae photobioreactor (PBR) in tropical climate building envelopes.

Furthermore, the study also suggests that microalgae photobioreactor on the building envelope not only able to generate a significant amount of biomass, it also allows the reduction of heat gain due to solar radiation through the building facade that leads to better thermal condition on the inside. With the right temperature and protection from the direct sunlight and glare, this may contribute toward achieving a higher level of thermal comfort among the user, thus improve their productivity. Other than that, the application of microalgae PBR on the building envelope is not only promoting energy efficiency strategies but also brings people closer to microalgae as it promotes the future of sustainable design using renewable natural resources. 


\subsection{Conclusion \& Recommendations}

The application of microalgae photobioreactor (PBR) is widely used all over the world, but the available options are limited as the design framework provided is not suitable for the Malaysian climate. This paper identified and determined the ten (10) design parameters for the application of microalgae PBR in the tropical climate building envelope. Parametric analysis with different design modules has been executed to analyse the compliance with the established design parameters. Based on the design modules, Design Module D complies with the ten (10) design parameters and provides the optimum usage of energy efficiency through the microalgae PBR. This study provides further research on the additional consideration in executing the design parameters, particularly on the application of microalgae PBR in the tropical climate region. The established design parameters also provide further direction for indepth study in quantifying the energy reduction within a building through the application of the microalgae PBR.

\section{References}

Bazdar, E., Roshandel, R., Yaghmaei, S. and Mardanpour, M. M. (2018). The effect of different light intensities and light/dark regime on the performance of photosynthetic microalgae microbial fuel cell. Bioresource Technology, 261, 350-360.

Biloria, N. and Thakkar, Y. (2019). Integrating algae building technology in the built environment: A cost and benefit perspective, Frontiers of Architectural Research, https://doi.org/10.1016/j.foar.12.004.

Chemodanov, A., Robin, A., and Golberg, A. (2017). Design of marine macroalgae photobioreactor integrated into building to support seagriculture for biorefinery and bioeconomy. Bioresource technology, 241, 1084-1093.

Elliot, S. (2016). Cohousing in the flower city: a carbon capture design. New York: Rochester Institute of Technology, Golisano Institute for Sustainability.

Elrayies, G. M. (2018). Microalgae: prospects for greener future buildings. Renewable and Sustainable Energy Reviews, 81, 1175-1191.

Fernández, F. G. A., Camacho, F. G., Pérez, J. A. S., Sevilla, J. M. F. and Grima, E. M. (1997). A model for light distribution and average solar irradiance inside outdoor tubular photobioreactors for the microalgal mass culture. Biotechnol. Bioeng. 55, 701-714. doi:10.1002/(SICI)1097-0290(19970905)55:5.

Heo, J., Shin, D. S., Cho, K., Cho, D. H., Lee, Y. J., \& Kim, H. S. (2018). Indigenous microalga Parachlorella sp. JD-076 as a potential source for lutein production: Optimization of lutein productivity via regulation of light intensity and carbon source. Algal research, 33, 1-7.

Ismail, M. A. and Al-Obaidi, K. M. (2019). Exploration in Using Algae to Enhance Indoor Environment in the Tropical Climate. 2nd Asia Conference on Energy and Environment Engineering (ACEEE), Hiroshima, Japan, pp. 25-29.

Jamaludin, Nazhatulzalkis; Mohammed, Nurul Izma; Khamidi, Mohd Faris; Ngah Abdul Wahab, Suriani. (2015). Thermal Comfort of Residential Building in Malaysia at Different Micro-climates. Procedia - Social and Behavioral Sciences, 170, 613-623.

Khan, M. I., Shin, J. H., and Kim, J. D. (2018). The promising future of microalgae: Current status, challenges and optimization of a sustainable and renewable industry for biofuels, feed and other products. Microbial Cell Factories, 17(36).

Klinthong, W., Yang, Y. H., Huang, C. H. and Tan, C. S. (2015). A review: microalgae and their applications in CO2 capture and renewable energy. Aerosol Air Qual Res. 15:712-42.

Krzemińska, I., Pawlik-Skowrońska, B., Trzcińska, M. and Tys, J.(2014). Infuence of photoperiods on the growth rate and biomass productivity of green microalgae. Bioprocess Biosyst Eng.37(4):735-41. https://doi. org/10.1007/s00449-013-1044-x.

Mata TM, Martins AA, Caetano NS. (2010). Microalgae for biodiesel production and other applications: a review. Renew Sust Energy Rev. $2010 ; 14: 217-32$.

Mirrahimi, S., Mohamed, M. F., Haw, L. C., Ibrahim, N. L. N., Yusoff, W. F. M., and Aflaki, A. (2016). The effect of building envelope on the thermal comfort and energy saving for high-rise buildings in hot-humid climate. Renewable and Sustainable Energy Reviews, 53, 1508-1519.

MS1525, Malaysian Standards. MS 1525:2014 Energy Efficiency and Use of Renewable Energy for Non-Residential Buildings-Code of Practice Air-Conditioning and Mechanical Ventilation (ACMV) System; SIRIM: Cyberjaya, Selangor, 2014; pp. 38-51

National Energy Efficiency Action Plan (NEEAP) Report. (2015). Ministry of Energy, Green Technology and Water. Malaysia.

Öncel, S.Ş., Köse, A. and Öncel, D.Ş. (2016). Façade integrated photobioreactors for building energy efficiency. 10.1016/B978-0-08-100546-0.00011-X.

Pagliolico, S. L., Verso, V. R. L., Bosco, F., Mollea, C. and La Forgia, C. (2017). A novel photo-bioreactor application for microalgae production as a shading system in buildings. Energy Procedia, Vol. 111:151-60. 
Pruvost, J. (2014). Symbiotic Integration Of Photobioreactors In A Factory building Façade For Mutual Benefit Between Buildings And Microalgae Needs. 10.13140/2.1.2076.1920. Qiu F. Algae architecture [Master]. TU Delft: Delft University of Technology; 2014.

Qahtan, A. M. (2019). Thermal performance of a double-skin façade exposed to direct solar radiation in the tropical climate of Malaysia: A case study. Case Studies in Thermal Engineering, 14, 100419.

Qiu F. Algae architecture [Master]. TU Delft: Delft University of Technology; 2014

Randrianarison, G., \& Ashraf, M. A. (2017). Microalgae: a potential plant for energy production. Geology, Ecology, and Landscapes, 1(2), 104-120.

Sathasivam, R., Radhakrishnan, R., Hashem, A., and Abd_Allah, E. F. (2017). Microalgae metabolites: A rich source for food and medicine. Saudi Journal of Biological Sciences.

Sierra, E., Acién, F., Fernández, J., Garcia, J., González, C. and Molina, E. (2018). Characterization of a flat plate photobioreactor for the production of microalgae. ChemEng J, Vol.138(1):136-47.

Singh, S. P. and Singh, P.(2015). Effect of temperature and light on the growth of algae species: a review. Renew Sust Energy Rev.50:431-44.

Slade, R., and Bauen, A. (2013). Micro-algae Cultivation for Biofuels: Cost, Energy Balance, Environmental Impacts and Future Prospects. Biomass and Bioenergy(53), 29-38.

Slegers, P. M. (2014). Scenario studies for algae production. Wageningen: Wageningen University.

Talaei, M., Mahdavinejad, M., Zarkesh, A. and Haghighi, H. M. (2017). A Review on Interaction of Innovative Building Envelope Technologies and Solar Energy Gain. 4th International Conference on Power Energy Systems Engineering, CPESE 2017. 141, pp. 25-29. Berlin, Germany: Elsevier Ltd.

Wilkinson, S., Stoller, P., Ralph, P., Hamdorf, B., Catana, L. and Kuzava, G. (2017). Exploring the Feasibility of Algae Building Technology in NSW. Procedia Engineering. 180. 1121-1130. 10.1016/j.proeng.2017.04.272.

Yeang, K. (2008). Interior Atmospheres: Biofuel from Algae (Vol. 78). John Wiley \& Sons, Ltd.

Zhang, X. (2015). Microalgae removal of CO2 from flue gas. London, UK: IEA Clean Coal Centre; [978-92-9029-572-3].

Zhou, X., Yuan, S., Wu, C., Song, B., and Peng, S. (2013). Potential Production and Distribution of Microalgae in China. Journal of Renewable and Sustainable Energy, $5(5)$.

Zr, D. L., and Mochtar, S. (2013). Application of Bioclimatic Parameter as Sustainability Approach on Multi-story Building Design in Tropical Area. Procedia Environmental Sciences, 17, 822-830. 